\title{
MACHADO DE ASSIS's THE TURKISH SLIPPER: TRANSLATION REVEALING ITS NARRATIVE WORKINGS
}

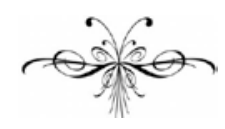

ROSALiA NEUMANN GARCIA

Resumo: Ao traduzir uma obra literária o tradutor deve também analisar o estilo, o ritmo e vários recursos de narrativa usadas por um autor na criação literária. O conto Chinela Turca, de Machado de Assis, traduzido para o inglês dentro do projeto de pesquisa Tradução Literária e seus Desdobramentos (UFRGS/IL, 2008), levanta várias questões quanto ao estilo e o tom do autor, além de trazer inúmeras revelações sobre o pacto criado entre autor e leitor/tradutor. Se por um lado, o tradutor lida com aspectos culturais e de época que são um desafio a seu trabalho, por outro lado, também deve lidar com considerações sobre a língua e a própria criação literária.

Palavras-chave: Palavras chave: tradução; Machado de Assis; narrativa.

\begin{abstract}
When translating a literary work, the translator should analyze style, rhythm and the many resources used by the author in his creation. The short story The Turkish Slipper, by Brazilian author Machado de Assis, translated to English as part of the research project Literary Translation and its Unfoldings (UFRGS/IL, 2008) brings up many issues related to its style and tone, besides interesting revelations surrounding the pact developed between author and reader/translator. If, on the one hand, a translator must deal with cultural/period elements that are a challenge in his/her work, there are considerations to be made also concerning language and literary creation itself.
\end{abstract}

Keywords: translation; Machado de Assis; narrative

The short story The Turkish Slipper, by renowned Brazilian author
Machado de Assis, presents curious narrative resources that a closer
reading will bring to the foreground and raise one's awareness about the writer's literary skill and talent. Published for the first time in 1875, it was later made a part of the collection Papéis Avulsos of 1882. 
The translation of the story into English was carried out by a research group at the Instituto de Letras, at UFRGS, from 2007 to 2009. ${ }^{1}$ The aim of the research (under the title Tradução Literária e seus Desdobramentos) was not only to carry out a competent translation, but also to study Machado's style and attempt to transport all the subtleties of his work to English. To do so, narrative studies were immensely useful since through them one can analyze with greater care such elements as narrative voice, focalization, rhythm and tone. One of the results of this work can be seen in the publication of A Machado de Assis Anthology (New Translations of Brazilian Classics) in a Kindle version. ${ }^{2}$ Other relevant results of the narratological study have been published in journals. ${ }^{3}$

It has come to our attention during our research on literary translation that when dealing with literature the translator is evidently a reader in several aspects. Communication between the real author ${ }^{4}$ of the source text and the real reader of the target text is made possible through the effort of a real translator, positioned externally to the text. The first action of the translator is to become a receptive agent of the source text and, with this, recreate and reassign the narrator, narrate and the reader of the text he/she is dealing with. Within this view, the translator then must face three levels in regards to literature and its translation, as described by Raymond Van Den Broeck:

a) on the linguistic level, i.e., the level of the natural language in which they [literary texts] are formulated (contextual information); b) on a situational pragmatic level, in that they are situated in space and time and form part of a system of socio-cultural norms and conventions (socio-cultural information); c) on the literary- aesthetic level in as much as they are structured according to the rules and standards of a literary tradition (intertextual information).

Van Der Broeck states that, considering the levels mentioned, the literary text follows principles of artistic structuration, allowing, therefore, the existence of deviations from the normal code.

In this sense, Machado de Assis' works present several challenges to the translator who will necessarily deal with these aspects of comprehension in order to carry out a translation that will attempt to live up to the standards of his writing. There are, of course, other elements often taken into consideration when translating, such as restraints of publication, etc., but these go beyond the scope of this article and will not be approached here. Nevertheless, in the research on Machado and the subsequent translations into English of his short stories, the group handled, on the one hand, the linguistic aspects of expressions, metaphors and ironies contained in the Brazilian

\footnotetext{
${ }^{1}$ The group, which I coordinated, included undergraduate and graduate students, among them, Cybele Alle, at the time an undergraduate student of Translation at Letras, who was in charge of translating The Turkish Slipper.

2 Found at <http://www.amazon.com/Anthology-Translations-Brazilian-Classics-ebook/dp/B00 5EHQJL8/ref=pd_rhf_se_p_t_1_F5E8>.

3 The research project has furthered its scope in the past few years by translating and analyzing (with the theoretical support of Polysystems Theory and narratology) the early 20th century Brazilian writer Mario de Andrade and, more recently, the southern regional writer Simões Lopes Neto.

${ }^{4}$ The study of narrative elements in Seymour Chatman's scheme (real author-implicit author-narratornarratee-implicit reader-real reader) are transposed to the insertion by Emer O`Sullivan (in Narratology Meets Translation Studies, or The Voice of the Translator in Children's Literature ) of the translator as a real reader taking on the position of narrator/narrate/implicit reader.
} 
author's works; and, on the other hand, extra-linguistic aspects of these same expressions that refer to the cultural context (Brazil in the late $19^{\text {th }}$ century, in the city of Rio de Janeiro). That our group was formed by members of two different cultures (Brazilian and Anglo-Saxon) was helpful in coping with these two sides.

The use of narratological studies in association to socio-cultural aspects allows the translator of the short stories to focus on more specific elements that are essential when capturing the wealth of metaphors, ironies and structures used by Machado in his works. For this article, I will approach the short story especially from this analysis. Since the translator, as mentioned before, is above all a reader, he or she will need to position him/herself for the task with some tools that can support his/her reading and subsequent translation.

The Turkish Slipper starts with the Bacharel Duarte preparing himself for what he considers a wonderful evening in the company of the lady of his dreams, "of the finest blonde hair and the most thoughtful blue eyes that our climate, so scarce of them, had ever produced.”(ASSIS, 2011, location 1514). In this initial part of the story, it is made evident to the reader that Duarte is captivated by a vision of beauty which is, as revealed by the narrative, not found easily in his part of the world. Thus, the vagaries of Duarte's desires are already at hand even before he receives the visit of Major Lopo Alves, which is described as a "true calamity." It is crucial that the reader realize the perspective from where the narrative is told, almost at all moments, in the story: Duarte is the focalizer, according to a term used both by Gérard Genette and Mieke Bal, and, due to this perception, the reader is made aware (though he or she might not realize fully at first) of whose perspective is being handed out to him/her.

To Genette it is clear that as one reads, the distinction between that character whose perspective guides the narrative and the narrator itself. As he says the crux of the matter is "more simply, the question who sees? And the question who speaks?" (GENETTE, 1983, p.186). In the case of The Turkish Slipper, there is no question that the narrator has placed the focalization in the hands of Duarte, the one character who throughout the narrative will conduct what the reader can see. Again, using Genette's classification, the narrative of the short story is one that contains an internal fixed focalization, since almost all we know of events, as readers, passes through Duarte and, at times, through the third person narrator, as will be shown below. With this in mind, as the story unfolds, we are eventually drawn into the dream world of the focalizer, Duarte. It is this strategy of the narrative that allows us to realize that the happenings that take place are becoming a bit farfetched and contrast, in a way, with the narrative until that moment. What is narrated gradually comes close to what one finds in a newspaper serial, almost what is known as a rag.

Thus, the setting is prepared for what the narrator refers to as "the place of sacrifice", and, in this, Lopo Alves is seen as "the torturer", desiring that there be no witnesses. We must note however, that Lopo Alves' perspective is never the issue in the story. If we see the Major in this very unfavorable light, it is due, mainly, to the focalization of Duarte. Thus we become complicit with the young man's position, one that is made clear by his posture: he has given up all hope of escaping from the reading that will ensue - except that his escape will occur in the subtlest way. How the narration slides into the dream is an example of superior craftsmanship in narration and is made all the more convincing because it is Duarte's mind which is at work. 
Duarte soon perceives that Lopo Alves' story is a mere example of "the most typical tousle-headed Romanticism” and is gradually enraged at being stuck in this tiresome situation. The third person narrator, at times, slips in to offer information and appears as a sympathetic observer of Duarte's plight. This is made apparent in the following:

It was almost eleven when he finished reading the second scene. Duarte could barely contain his rage; it was already impossible to go to Rio Comprido. It is not out of the question to assume that, had the Major breathed his last at that moment, Duarte would have thanked Divine Providence for his death. The bacharel's sentiments made such ferocity hard to believe; but reading a bad book is capable of producing even more astounding phenomena. (ASSIS, 2011, location 1555).

It is evident from the excerpt above that there is a shift in narrative perspective in the phrase that begins with "It is not out of the question to assume that..." in which the narrator, for a moment, offers the reader a possible interpretation of Duarte's frustration, based on the very perspective that has been given to Duarte himself. The narrator goes further, appealing to the reader's sympathy as well, when it is made clear that, though Duarte's "ferocity [is] hard to believe", one can relate to it when one remembers that "reading a bad book is capable of producing even more astounding phenomena." (ASSIS, 2011, location 1555). In this carefully placed comment lies Machado de Assis' ability to bring together narrative resources: on the one hand, Duarte's feelings and thoughts brought to the fore in such a way as to bring us closer to his plight; on the other, the "interference" of the third person narrator giving the reader more reason to understand events. It is essential that we understand this matter of different narrative resources so as not to fall into the mistake made so often in the past in which Machado de Assis (implied author) is seen as being the entity making such comments. As Maria Luisa Nunes states, what Machado de Assis does at times is use " 'romantic parody', or the parody of realism in which the narrators make an issue of their presence.” (NUNES, 1983, p. 78).

Duarte's "bodily eyes" seem to lose focus as his mind drifts off to the image of the lady he will regretfully not see that evening, and we are led to believe that the young man has merely missed most of Lopo Alves' reading. As Duarte is drawn back to the figure before him, he is surprised to see the Major's anger as he stomps away, whether offended or not, Duarte cannot tell for sure. Events begin to unroll in the most contradictory manner, as the attentive reader soon realizes. A man claiming to be a policeman enters accusing Duarte of stealing a slipper that is first referred to be "worth little or nothing at all" and soon after is described as being "worth several dozen contos de réis; [...] adorned with the finest diamonds, which make it uniquely valuable.” (ASSIS, 2011, location 1575). Furthermore, the agent reports that the story of the Turkish slipper and how it made its way into the possession of a wealthy lady traveling to Egypt seems "truly miraculous, and, to my eyes, perfectly untruthful." (ASSIS, 2011, location 1575). Within the frame of irrationality presented by the introduction of the agent's arguments, Duarte is presented as being level-headed and certain that a mistake is being made. The contrast between the action taking place and Duarte's view of matters is made clear because there has been no change in whose general perspective we are given. 
At this moment one sees that Machado has established a sort of pact with his reader, one that this reader must accept or become a victim to. There is now a narrative within a narrative, or in the words of Mieke Bal, an embedded narrative, one that must be distinguished in its rhythm and tone. The comments made by the socalled policeman directly refer to Duarte's interests in "dating blonde ladies with impunity and perhaps marry[ing] them", (ASSIS, 2011, location 1581), and affect Duarte's previous judgment. Could this possibly be the action of some rival? Duarte' reasoning, however, is that if these people, who have now forced him into a carriage, are the police, order will soon be restored. The turnabout of events is melodramatic, however. In the new style that has taken over the narrative, a revelation is made: not only are the men who have captured him not the police, but a bizarre explanation is given:

This gentleman and I are a duo. I, you and he are a trio. Well, a trio is not better than a pair; it is not, it cannot be. A couple is the ideal. You probably haven't understood me, have you? (ASSIS, 2011, location 1588).

The sequence of events contains all the elements of a classical adventure story: the coach in which Duarte finds himself races through the streets and soon enough it halts at their destiny where the young man must blindfold himself and is taken through passages and down stairways, all the time hearing bits and scraps of talk, though not really understanding anything that is being said.

Duarte finally finds himself in a vast room where what he sees denotes "perhaps overmuch variety of ornaments", though it is elegant and refined. The room reflects the overly-wrought story the Major had been telling Duarte earlier, clearly an association can be made here with "the tousle-headed Romanticism" mentioned before.

Figures representing Church and Military power soon appear as well: a priest, who shall marry Duarte to a sylph-like creature whose face resembles Cecilia's in the most extraordinary way, and a lieutenant - both turning out to be the same person. The scene mentioned reflects Duarte's innermost concerns with being taken advantage of due to his wealth; for though he would like to marry Cecilia, the woman of his dreams in many respects, his fear that she does not feel true love for him is evident. He is told very cleary that

Three things you are going to do right now, sir," the elder continued impassively. "First, wed her; second, write your will; third, swallow a drug from the Levant... (ASSIS, 2011, location 1626).

In other words, the nagging suspicion that holds Duarte in doubt as to whether he should get married or not is revealed in the words of the old man. The interests of others may not appear clearly on their faces and in their gestures, but do come out in this odd exchange between Duarte and the man. The reference to Nehemiah and the Levant are curious as well. Nehemiah, known as a minor prophet, was a crucial figure in the fortification of Jerusalem, urging the people to repair breaches in the city wall and setting up guards to help in the defense of external threats. In a certain way, Duarte also has set himself in a position of defense against those who might threaten him, whether financially or amorously, and the reference to Nehemiah is not a coincidence. The "drug from the Levant" which Duarte must swallow after writing out his will, recalls the area referred to in the Bible which the 
Persians needed to protect from invasion as well and the role Nehemiah had as cupbearer in the palace of the Persian king Artaxerxes.

Duarte is given a hint by the priest/ lieutenant that he may escape through the window, which he promptly does, in an exciting example of the swashbuckling adventure one can read in romantic novels. After racing away from yet another pursuer through a garden he finds himself at the steps of a house. Lopo Alves is seated in a room, holding a paper which initially is seen as being an important newspaper in Rio de Janeiro at the time, but can be later associated to the long story the Major had been reading to Duarte. The Major asks Duarte what he thinks of the story to which the young man replies positively. After all, sleep had rescued him, as he later muses,

Nymph, sweet friend, restless and fertile fantasy, you saved me from a terrible play with an original dream, replacing boredom with a nightmare: it was a good bargain. (ASSIS, 2011, location 1657).

Cecilia had been transfigured into the saving nymph of what now is understood as dream, a fantasy triggered by the story told by the Major, but colored with Duarte's own concerns and fancies. The idea behind this may be interpreted in different ways: has Duarte been "rescued", so to speak, from going to the ball and revealing too much of his feeling for the young woman of his dreams, when he falls asleep? Is Cecilia, perhaps, a possible true love? Certainly one can see Cecilia as a "restless and fertile fantasy", a promise, a chimera, something lovely and frightening at the same time.

Duarte knows one thing at this point: not only was the dream a good bargain, but a valuable lesson. The nymph has shown "once again, that the best drama is in the playgoer, not on the stage." (ASSIS, 2011, location 1657). It is clear that as "playgoers", as we read any work by Machado de Assis, we are expected to participate as "an essential precondition for communication between the author and the reader." (NUNES, 1983, p. 80). If, as readers, we fail to participate, we may not achieve the ultimate experience of the story, we may lose the subtle revelations being offered to us.

Machado de Assis' intentions may not be fully captured - after all, any authorial intention can only be construed by the reader. However, the reader of Machado's works is invited to unfold the inner workings not only of the human psyche, but of the acts of writing and reading themselves. When, in the course of reading, do we realize the joke is on Duarte and on us? The dream sequence is marked in a different tone, certainly a shrewd device used to put us on the alert. Machado has used an approach that reveals that he is not bound to rules and schools. He is playful in his gentle exhortations that we, as readers, see beyond the obvious.

The same effort to perceive the intentions of the text is made on the part of the translator. As Raquel Oliveira says, Machado places his work in the hands of the reader and "symbolically, it seems to us, that he is also handing us the task of recognizing all its multiplicity”. (OLIVEIRA, 2010, p. 4, my translation). It is in our capacity to understand the significance of the dream sequence, ultimately, as a reflection of the concerns of Duarte as a wealthy young man who is both fascinated and uneasy about his emotional future. It is also possible to perceive the collaboration Machado requires from the reader in order for him/her to understand the author's discussion on literature genres themselves. 
Rosalia Neumann Garcia

rosalia0806@gmail.com

Universidade Federal do Rio Grande do Sul

\section{Referências}

BAL, Mieke. Narratology: introduction to the theory of narrative. Toronto: University of Toronto Press, 2009.

CHATMAN, S. (1978): Story and Discourse. Narrative Structure in Fiction and Film. Ithaca, London: Cornell University Press.

EVEN-ZOHAR, Itamar. Polysystem Studies, in Poetics Today 11:1. Durham: Duke University Press, 1990.

GARCIA, Rosalia; ALEXANDER, Ian (ed.). A Machado de Assis Anthology (New Translations of Brazilian Classics) [Kindle Edition], 2011, encontrada no site $<$ http://www.amazon.com/Anthology-Translations-Brazilian-Classicsebook/dp/B005EHQJL8?qid=1349554791>.

NUNES. Maria Luisa. The Craft of an Absolute Winner: Characterization and Narratology in the Novels of Machado de Assis. Westport, Conn: Greenwood Press, 1983.

OLIVEIRA, Raquel Peralva Martins de. A chinela turca: A contribuição dos antigos e a intuição da modernidade. Encontrado no site <http://www.uf jf.br/darandina/files/2010/01/Raquel-Peralva-Martins-de-Oliveira.pdf $>$.

O'SULLIVAN, Emer. Narratology meets Translation Studies, or, The Voice of the Translator in Children's Literature, in Meta: Translators' Journal, vol. 48, 1-2, 2003, p. $197-207$. 